\title{
Prediksi Laju Pembentukan Air Asam Tambang dengan Metode Column Leaching Test
}

\author{
Nur Ilham Situru ${ }^{1 *}$, Muhammad Ramli ${ }^{1}$, Muhammad Thamrin ${ }^{1}$ \\ ${ }^{1}$ Departemen Teknik Pertambangan, Fakultas Teknik, Universitas Hasanuddin \\ Jl. Poros Malino km. 6, Bontomarannu, Kabupaten Gowa, Sulawesi Selatan 92171 \\ *Email: nurilhamsituru7@gmail.com
}

DOI: 10.25042/jpe.112019.06

\begin{abstract}
Abstrak
Salah satu permasalahan lingkungan pada kegiatan pertambangan batubara adalah pembentukan air asam tambang. Dalam rangka pengendalian dampak lingkungan yang terkait, maka perlu dilakukan prediksi pembentukan air asam tambang. Air asam tambang terjadi dengan adanya interaksi antara material yang berpotensi pembentuk air asam tambang dengan oksigen, bakteri, dan air. Penelitian ini bertujuan untuk menganalisis potensi pembentukan air asam tambang berdasarkan karakteristik material. Metode penelitian dilakukan dengan menggunakan uji statik dan uji kinetik. Metode uji statis mengklasifikasikan material sesuai kemampuan untuk menghasilkan asam bersih dengan parameter uji berupa $\mathrm{pH}$ pasta, total sulfur, Acid Neutralizing Capacity (ANC), Net Acid Generation (NAG), Maximum Potential Acid (MPA), dan Net Acid Producing Potential (NAPP). Metode uji kinetik memprediksi laju pembentukan asam suatu material. Uji kinetik menggunakan metode Column Leaching Test terhadap material yang didesain sedemikian rupa untuk mewakili kondisi lapangan. Parameter metode kinetik yaitu $\mathrm{pH}$, konduktivitas listrik, asiditas, alkalinitas, kandungan sulfat, dan kandungan logam terlarut (Fe, Mn, dan Cd). Hasil uji statik mengklasifikasikan material ke dalam kategori material NAF Non-Acid Forming (NAF), Potential Acid Forming (PAF) dan Uncertain(UC). Hasil Metode Column Leaching membagi material dalam kategori kolom yang berpotensi dan tidak berpotensi membentuk air asam tambang. Kolom yang berpotensi membentuk air asam tambang terjadi pada kolom dengan jumlah tonase material PAF yang banyak atau yang berada pada lapisan atas sehingga bereaksi dengan oksigen. Kolom yang tidak berpotensi menghasilkan air asam tambang pada kolom dengan material PAF berada di lapisan tengah atau dicampur dengan material NAF.
\end{abstract}

\begin{abstract}
Prediction of Acid Mine Drainage Forming using Method of Column Leaching Test. One of the environmental problems in coal mining activities is the formation of acid mine drainage. Prediction of the formation of acid mine drainage is important as an effort to control environmental impacts. Acid mine water occurs with interactions between potentially acid-forming material with oxygen, bacteria and water. Objective of study is to analyze the potential for acid mine drainage forming based on material characteristics. The research method was carried out using static and kinetic tests. The static test method classifies materials according to the ability to produce clean acids with observed parameters such as paste $\mathrm{pH}$, total sulfur, Acid Neutralizing Capacity (ANC), Net Acid Generation (NAG), Maximum Potential Acid (MPA), and Net Acid Producing Potential (NAPP). The Kinetic test method predicts the rate of acid-forming of a material. The kinetic test uses the Column Leaching Test Method by using material with composition designed to represent field condition. The kinetic method parameters are $\mathrm{pH}$, electrical conductivity, acidity, alkalinity, sulfate content, and dissolved metal content (Fe, Mn, and Cd). Results of the static test classified the material into NAF Non-Acid Forming (NAF), Potential Acid Forming (PAF) and Uncertain (UC) material categories. The results of the Column Leaching Method classified the material into categories of potential and no potential to form acid mine water. The columns that have the potential to form acid mine drainage occur in columns with large amounts of tonnage of PAF material or those in the upper layer so that it reacts with oxygen. The columns that have no potential to produce acid mine drainage in columns with PAF material are in the middle layer or mixed with NAF material.
\end{abstract}

Kata Kunci: Air asam tambang, uji statik, uji kinetik, uji kolom pelindian

\section{Pendahuluan}

Kegiatan penambangan merupakan kegiatan dengan daya ubah lingkungan yang sangat besar. Indonesia sebagai salah satu negara penghasil batubara di dunia yang terus berupaya meningkatkan hasil produksinya akan memiliki potensi timbulnya dampak lingkungan yang semakin besar pula. Permasalahan lingkungan utama yang terjadi pada penambangan batubara adalah air asam tambang. Air asam tambang terbentuk dari air hujan atau air tanah yang bercampur dengan mineral sulfida yang 
terkandung dalam batubara yang menyebabkan air tersebut bersifat sangat asam dan mengandung logam dengan konsentrasi tinggi [1].

Langkah awal yang dapat dilakukan untuk mencegah air asam tambang yaitu mengetahui potensi pembentukannya terhadap suatu material yang dapat dilakukan melalui uji statik. Pengujian statik dilakukan dengan menentukan kandungan sulfur dan jumlah asam yang dapat dinetralisir oleh material. Uji statik digunakan untuk mengelompokkan material kedalam karakteristik batuan sebagai PAF (Potentially Acid Forming) atau NAF (Non-Acid Forming). Penerapan metode pengujian statik ini masih memiliki keterbatasan sehingga untuk kasus tertentu dapat diperoleh kondisi batuan yang tidak jelas antara PAF atau NAF yang kemudian dinyatakan sebagai UC (Uncertain). Hasi uji statik akan akan dilengkapi dan dikonfirmasi dengan uji kinetik [2].

Pengujian kinetik digunakan untuk menentukan laju relatif pelapukan mineral sulfida dari reaksi oksidasi dan analisis penetralan oleh mineral alkali serta uji keterlarutan logam pada air asam tambang. Perkembangan uji kinetik pada skala laboratorium yang sudah lazim dilakukan adalah Metode Column Leaching Test (Uji kolom pelindian). Hasil pengujian kinetik memberikan informasi laju reaksi terhadap waktu dan periode waktu berlangsungnya reaksi [3].

Penelitian ini dilakukan dengan menggabungkan kedua metode uji statik dan uji kinetik untuk memprediksi laju pembentukan air asam tambang. Penelitian ini dilaksanakan di PT. Adaro Indonesia Kabupaten Tabalong, Provinsi Kalimantan Selatan dengan menggunakan fasilitas pengujian yang tersedia pada Coal Laboratory Service Department di KM. 67 Hauling Road. Keterbatasan referensi dan informasi tentang karakteristik material pembentuk air asam tambang menjadi kendala dalam mengidentifikasi kondisi timbunan material buangan tambang (disposal). Oleh karena itu, proses pengujian dilakukan dengan sampel yang diambil dari lokasi penambangan PT. Adaro Indonesia. Sampel-sampel tersebut kemudian dicampur atau disusun dengan perbandingan dan urutan tertentu sebagai pendekatan kondisi lapangan yang mungkin terjadi. Dengan demikian, material hasil rekayasa lapangan ini diharapkan sebagai representasi dari kondisi lapangan yang dapat berpengaruh terhadap pembentukan air asam tambang.

\section{Metode Penelitian}

Penelitian ini diawali dengan pengambilan sampel tanah dan air dari lokasi penambangan. Sampel tanah yang diambil berupa sampel mud pada lokasi Settling Pond - 3 (SP-3) Wara, dan sampel PAF, NAF, serta Fly Ash Bottom Ash $(F A B A)$ pada lokasi gudang sampel perusahaan. Sampel air diperoleh dari hasil penyiraman sampel tanah.

Penelitian dilakukan dengan menggunakan peralatan crusher, mixer, grinding, $\mathrm{pH}$ meter, alat Sulfur Determinator Behr CS50 HT-1550, alat titrator automatik, botol polietilen, alat penyiram, alat pengukur EUTECH PC2700 Benchtop Meter, Portabel Datalogging Spectrophotometer, dan Atomic Absorption Spectrophotometry $(A A S)$. Bahan yang digunakan antara lain sampel tanah (PAF, NAF, Mud SP 3 Wara, FABA), air hujan atau air deionisasi larutan $\mathrm{HCl}$ larutan $\mathrm{NaOH} 0,1 \mathrm{~N}$, larutan $\mathrm{H}_{2} \mathrm{O}_{2}$, aquades, kolom, kertas saring, dan corong.

Sampel yang telah diperoleh dilakukan uji statik untuk mengklasifisi potensi pembentukan asam bersih. Uji statik yang dilakukan mengacu pada SNI 6597:2011 tentang Uji Statik Pengidentifikasian Sumber Air Asam Tambang. Standar ini digunakan untuk mengetahui potensi pembentukan suatu asam dalam satu waktu dengan melakukan pengukuran terhadap parameter uji statik yaitu $\mathrm{pH}$ pasta, total sulfur, ANC (Acid Neutralizing Capacity), NAG (Net Acid Generation). Selanjutnya berdasarkan data tersebut dihitung nilai MPA (Maximum Potential Acid), dan NAPP (Net Acid Producing Potential). Nilai MPA diperoleh dari perkalian antara konsentrasi total sulfur (\%) dengan asumsi jika batuan yang memiliki berat 1 ton dan memiliki TS sebesar $1 \%$ akan menghasilkan asam sulfat sebesar 30,62 Kg. Nilai NAPP didapatkan dari hasil pengurangan antara MPA dengan ANC (Acid Neutralizing Capacity).

Setelah pelaksanaan uji statik dilanjutkan dengan uji kinetik. Uji kinetik dilakukan untuk memprediksi laju pembentukan asam suatu material. Uji ini menggunakan metode Column Leaching Test yang berisi material-material dengan komposisi dan susunan tertentu yang dapat merepresentasikan kondisi lapangan. 
Metode ini menggunakan kolom yang diisi dengan $6 \mathrm{~kg}$ sampel material per kolom. Kolom pelindian yang diuji pada penelitian berjumlah 10 kolom dengan komposisi material berbeda. Sampel pada kolom tersebut dilakukan penyiraman menggunakan air hujan atau air deionisasi. Guna mengetahui perubahan sifat material dilakukan penyiraman atau periode pelindian sebanyak 10 kali.

Metode pelindian menggunakan sistem Free Draining Column Testing agar hasil yang diinginkan lebih mendekati kondisi lapangan. Pengujian dilakukan secara langsung di area terbuka dan di bawah terik sinar matahari sehingga kolom sesuai dengan kondisi lapangan. Parameter yang diuur dalam metode kinetik ini meliputi pH, konduktivitas (EC), asiditas, alkalinitas, kandungan sulfat, dan kandungan logam terlarut $(\mathrm{Fe}, \mathrm{Mn}$, dan $\mathrm{Cd})$. Data yang dianalisis pada uji ini adalah klasifikasi PAF dan NAF. Variabel tersebut dibandingkan dan dicari hubungan antara keduanya untuk mendapatkan desain model kolom dengan mempertimbangkan kriteria material dan volume total yang dimiliki.

\section{Prediksi Pembentukan Air Asam Tambang}

\subsection{Uji Statik}

Dalam uraian sebelumnya telah dijelaskan bawah sampel yang digunakan dalam penelitian ini adalah mud dari settling pond-3 (SP 3-Wara) dan sampel dari gudang penyimpanan sampel berupa sampel PAF, NAF, dan FABA. Hasil pengukuran parameter uji dari sampel-sampel tersebut diperoleh hasil seperti pada Tabel 1.

Tabel 1. Hasil pengujian statik

\begin{tabular}{|c|c|c|c|c|c|}
\hline \multicolumn{2}{|c|}{ Parameter } & \multirow{2}{*}{$\begin{array}{c}\text { Mud SP 3 } \\
4,97\end{array}$} & \multirow{2}{*}{$\begin{array}{r}\text { PAF } \\
2,52\end{array}$} & \multirow{2}{*}{$\frac{\mathbf{N A F}}{7,47}$} & \multirow{2}{*}{$\begin{array}{r}\text { FABA } \\
12,35\end{array}$} \\
\hline pH Pasta & - & & & & \\
\hline $\mathrm{TS}$ & $\%$ & 0,25 & 2,40 & 0,09 & 0,04 \\
\hline ANC & $\begin{array}{l}\mathrm{kg} \cdot \mathrm{H}_{2} \mathrm{~S} \\
\mathrm{O}_{4} / \text { ton }\end{array}$ & 23 & 18 & 34 & $>500$ \\
\hline MPA & $\begin{array}{l}\mathrm{kg} \cdot \mathrm{H}_{2} \mathrm{~S} \\
\mathrm{O}_{4} / \text { ton }\end{array}$ & 8 & 74 & 3 & 1 \\
\hline NAPP & $\begin{array}{l}\mathrm{kg} \cdot \mathrm{H}_{2} \mathrm{~S} \\
\mathrm{O}_{4} / \mathrm{ton}\end{array}$ & -15 & 56 & -31 & -499 \\
\hline pH NAG & - & 4,2 & 2,1 & 7,3 & 11,9 \\
\hline $\begin{array}{c}\text { NAG pH- } \\
4.5\end{array}$ & $\begin{array}{l}\mathrm{kg} \cdot \mathrm{H}_{2} \mathrm{~S} \\
\mathrm{O}_{4} / \text { ton }\end{array}$ & $<1$ & 43 & 0 & 0 \\
\hline $\begin{array}{c}\text { NAG pH- } \\
7.0\end{array}$ & $\begin{array}{l}\mathrm{kg} . \mathrm{H}_{2} \mathrm{~S} \\
\mathrm{O}_{4} / \text { ton }\end{array}$ & 4 & 59 & 0 & 0 \\
\hline
\end{tabular}

Berdasarkan atas hasil pengukuran nilai $\mathrm{pH}$ NAG-nya, sampel Mud SP 3 Wara dapat dikategorikan dalam golongan pembentuk air asam tipe 2 yaitu potensi pembentuk asam kapasitas rendah (PAF-LC). Hal tersebut dikarenakan nilai $\mathrm{pH}$ uji NAG-nya didapatkan lebih kecil dari 4,5 dan nilai NAG $\mathrm{pH}-4,5$ didapatkan lebih kecil dari $5 \mathrm{kgH}_{2} \mathrm{SO}_{4} /$ ton. Namun demikian, berdasarkan nilai NPP-nya dapat dikategorikan ke dalam golongan tipe 1 yaitu bukan pembentuk asam (NAF) dikarenakan hasil nilai NAPP yang didapatkan bernilai negatif. Dalam hal ini terjadi konflik pada pengklasifikasian terhadap nilai NAG dan NAPP (NAPP negatif tetapi $\mathrm{NAG} \mathrm{pH} \leq 4.5$ ). Pada kasus seperti ini, maka sampel ini dikategorikan sebagai sampel tidak pasti (Uncertain/UC).

Sampel terduga NAF berdasarkan hasil pengukuran statik dapat dikategorikan dalam golongan pembentuk air asam tipe 1 yaitu bukan pembentuk asam (NAF). Hal tersebut dikarenakan nilai uji pH NAG lebih besar dari 4,5 dan hasil nilai NAPP yang didapatkan bernilai negatif.

Sampel terduga PAF berdasarkan hasil pengukuran statik dapat dikategorikan dalam golongan pembentuk air asam tipe 4 yaitu potensi pembentuk asam kapasitas tinggi (PAF-HC). Hal tersebut dikarenakan nilai $\mathrm{pH}$ uji NAGnya didapatkan lebih kecil dari 4,5, nilai NAG pH-4,5 didapatkan lebih besar dari $5 \mathrm{~kg} \cdot \mathrm{H}_{2} \mathrm{SO}_{4} /$ ton, nilai NAPP yang didapatkan lebih besar dari 10 $\mathrm{kg} . \mathrm{H}_{2} \mathrm{SO}_{4} / \mathrm{ton}$, dan nilai dari uji $\mathrm{pH}$ pasta yang diperoleh lebih kecil dari 4,5.

Sampel FABA berdasarkan hasil pengukuran statik dapat dikategorikan dalam golongan pembentuk air asam tipe 1 yaitu bukan pembentuk asam (NAF). Hal tersebut dikarenakan nilai uji pH NAG lebih besar dari 4,5 dan hasil nilai NAPP yang didapatkan bernilai negatif.

\subsection{Uji Kinetik}

Uji kinetik dengan column leaching test menggunakan 10 kolom yang didesain berdasarkan pertimbangan potensi pembentukan asam dari uji statik sebagaimana yang diklasifikasikan sebagai PAF atau NAF. Kolom dibuat menggunakan sampel PAF, sampel NAF, dan sampel FABA. Material tersebut digabung dalam satu kolom dengan variasi posisi lapisan 
yang dapat ditempatkan pada bagian atas, tengah dan bawah. Satu kolom dibuat dengan mencampur material PAF, NAF, dan FABA. Sampel PAF yang digunakan relatif lebih banyak daripada sampel NAF dikarenakan jumlah tonase PAF di lapangan lebih banyak. Sampel Mud SP 3 Wara terpisah tersendiri karena jumlah yang sedikit. Karakteristik dan komposisi desain kolom disajikan pada Tabel 2.

Tabel 2. Rancangan model Column Leaching Test

\begin{tabular}{|c|c|c|c|c|}
\hline $\begin{array}{l}\text { Kode } \\
\text { Kolom }\end{array}$ & $\begin{array}{c}\text { Komposisi } \\
\text { sampel } \\
\text { (Kg) }\end{array}$ & $\begin{array}{c}\text { Urutan } \\
\text { Lapisan }\end{array}$ & $\begin{array}{l}\text { Berat } \\
\text { Total } \\
(\mathrm{Kg})\end{array}$ & Litologi \\
\hline A & 6 PAF & PAF & 6 & Mudstone \\
\hline \multirow[t]{2}{*}{ B } & $6 \mathrm{NAF}$ & NAF & 6 & Mudstone \\
\hline & $1 \mathrm{FABA}+4$ & PABA & & \\
\hline \multirow[t]{2}{*}{$\mathrm{C}$} & $\mathrm{PAF}+1$ & PAF & 6 & Mudstone \\
\hline & NAF & NAF & & \\
\hline \multirow{3}{*}{ D } & $3 \mathrm{PAF}+3$ & PAF & 6 & \\
\hline & $\mathrm{NAF}$ & NAF & 6 & Mudstone \\
\hline & $2 \mathrm{NAF}+1$ & NAF & & \\
\hline \multirow[t]{3}{*}{$\mathrm{E}$} & $\mathrm{PABA}+3$ & FABA & 6 & Mudstone \\
\hline & PAF & PAF & & \\
\hline & $4 \mathrm{PAF}+1$ & NAF & & \\
\hline \multirow[t]{3}{*}{$\mathrm{F}$} & $\mathrm{FABA}+1$ & PAF & 6 & Mudstone \\
\hline & NAF & FABA & & \\
\hline & $4 \mathrm{PAF}+1$ & PAF & & \\
\hline \multirow[t]{3}{*}{ G } & $\mathrm{FABA}+1$ & FABA & 6 & Mudstone \\
\hline & NAF & NAF & & \\
\hline & $1 \mathrm{NAF}+4$ & NAF & & \\
\hline \multirow[t]{3}{*}{$\mathrm{H}$} & $\mathrm{PAF}+1$ & PAF & 6 & Mudstone \\
\hline & NAF & $\mathrm{NAF}$ & & \\
\hline & $4 \mathrm{PAF}+1$ & & & \\
\hline I & $\begin{array}{c}\mathrm{NAF}+1 \\
\text { FABA }\end{array}$ & MIX & 6 & Mudstone \\
\hline J & 6 SP 3 Wara & SP & 4 & Mudstone \\
\hline
\end{tabular}

Pada uji kinetik, pengukuran parameter uji dilakukan pada air pelindian dari column leaching test. Hasil pengukuran yang diperoleh ditampilkan pada Gambar $1-8$ berikut.

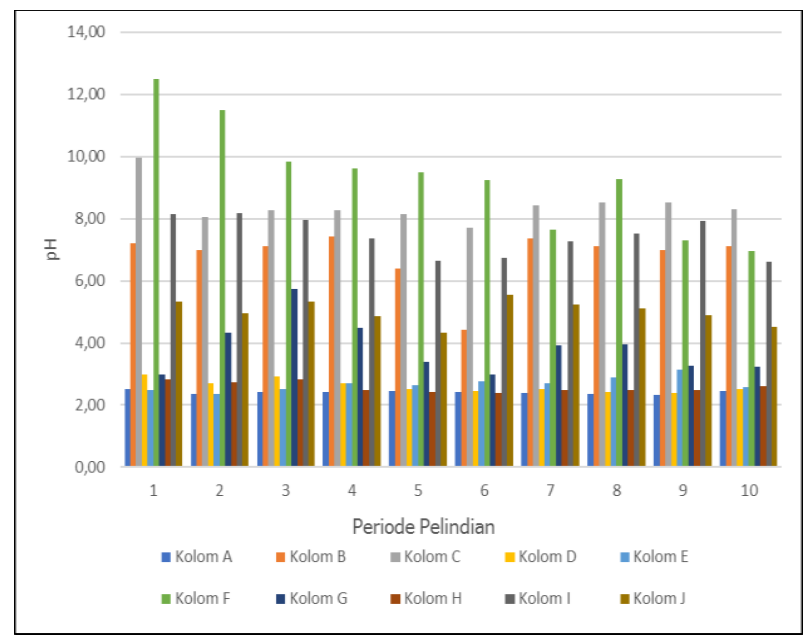

Gambar 1. Perubahan nilai pH

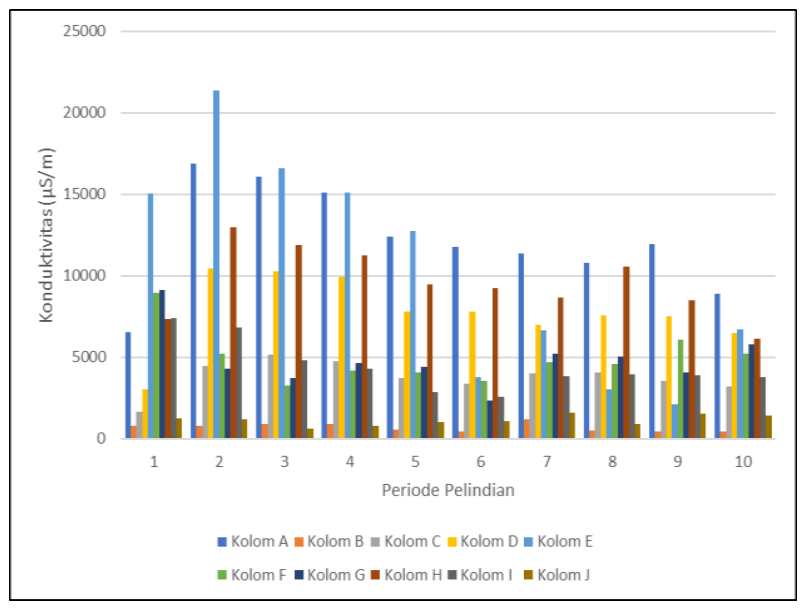

Gambar 2. Perubahan nilai konduktivitas

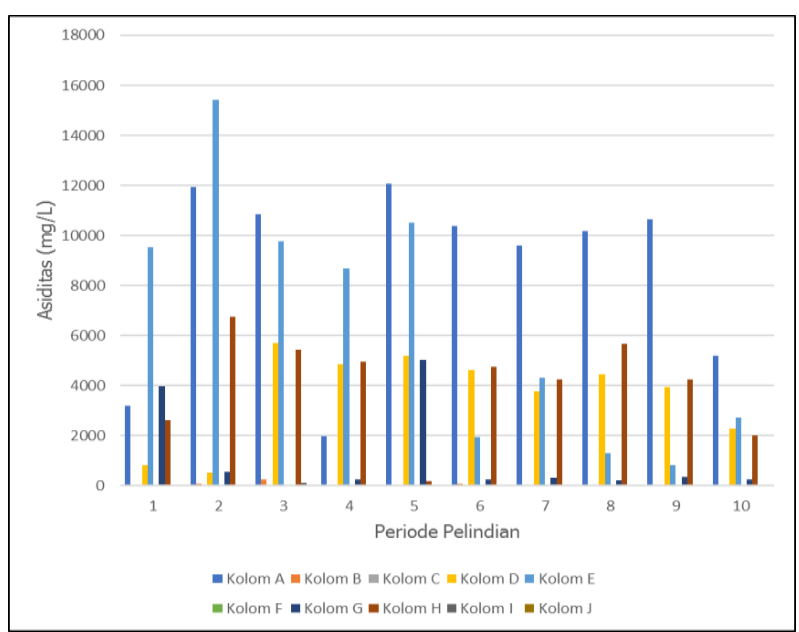

Gambar 3. Perubahan nilai asiditas



Gambar 4. Perubahan nilai alkalinitas 


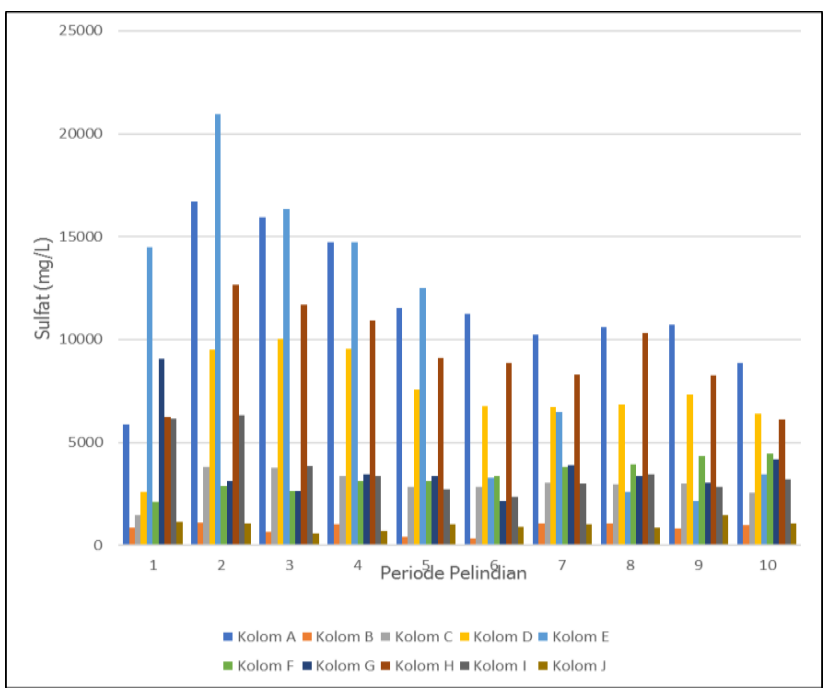

Gambar 5. Perubahan nilai sulfat

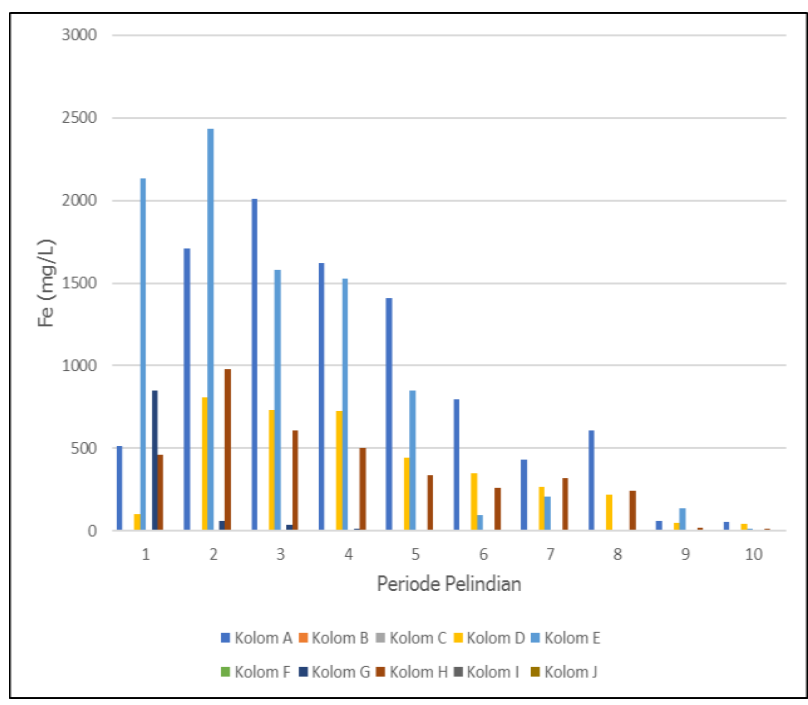

Gambar 6. Perubahan nilai Fe terlarut column test

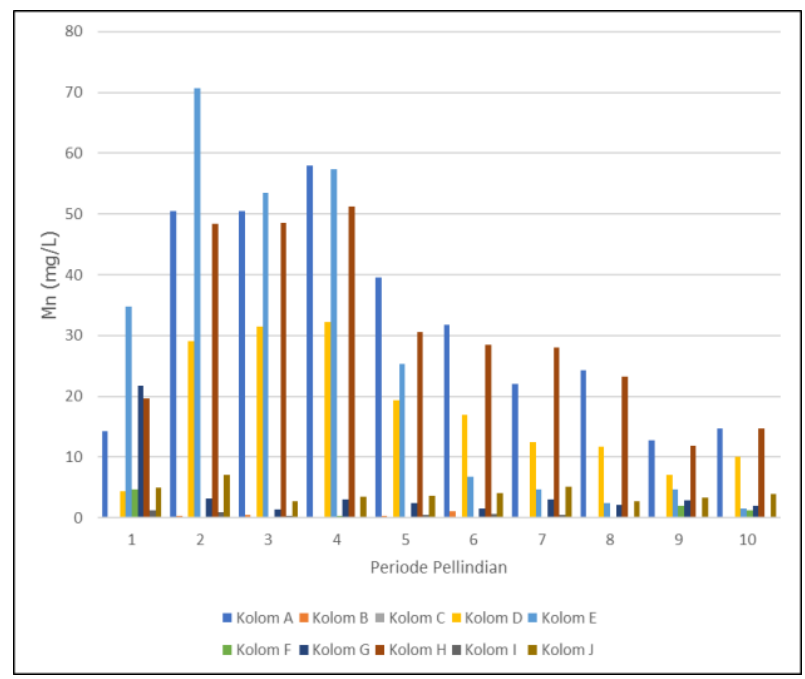

Gambar 7. Perubahan nilai Mn terlarut

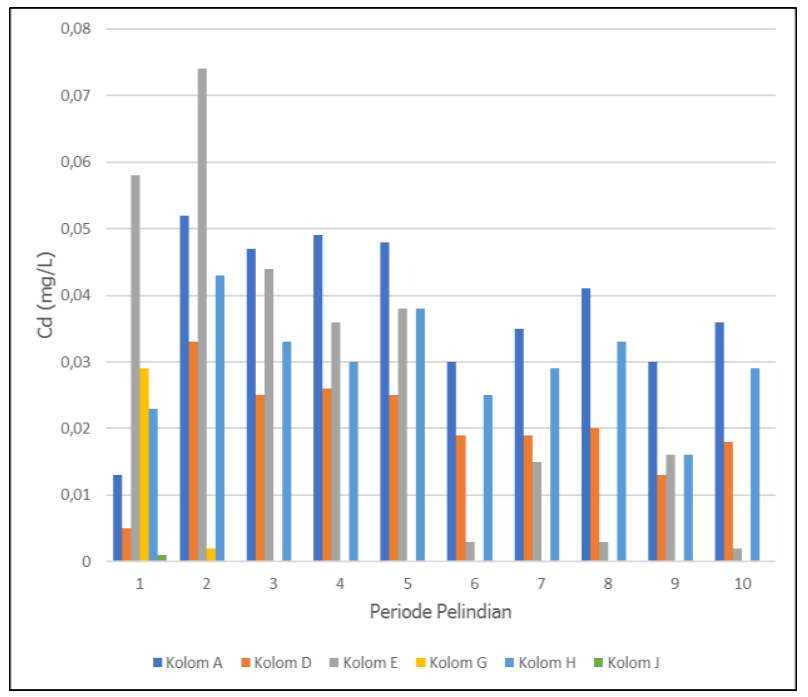

Gambar 8. Perubahan nilai Cd terlarut

\subsection{Potensi Pembentukan Air Asam Tambang}

Analisis potensi pembentukan air asam tambang pada setiap kolom didasarkan pada parameter hasil pengujian yang ditunjukkan pada Gambar 1 - 8. Kolom yang berpotensi dalam pembentukan air asam tambang meliputi;

1. Kolom $\mathrm{A}$; dicirikan dengan $\mathrm{pH}$ yang sangat rendah, dan nilai konduktivitas, asiditas, kandungan sulfat, serta kandungan logam terlarut yang sangat tinggi.

2. Kolom D; dicirikan oleh $\mathrm{pH}$ sangat rendah, nilai konduktivitas dana asiditas yang tinggi serta membentuk ion sulfat yang berlebih, dan logam terlarut yang sangat banyak.

3. Kolom E; dicirikan oleh $\mathrm{pH}$ yang sangat rendah, dan nilai konduktivitas, asiditas, dan kandungan logam yang tinggi serta membentuk ion sulfat yang berlebih.

4. Kolom $\mathrm{G}$; dicirikan oleh $\mathrm{pH}$ yang sangat rendah, nilai konduktivitas, asiditas, dan kandungan logam yang tinggi, serta membentuk ion sulfat yang berlebih.

5. Kolom $\mathrm{H}$; dicirikan oleh $\mathrm{pH}$ yang sangat rendah, nilai konduktivitas, asiditas, dan kandungan logam dan sulfat yang berlebih.

6. Kolom J; dicirikan oleh $\mathrm{pH}$ yang rendah, nilai konduktivitas, sulfat, dan logam Mn yang relatif tinggi. Nilai asiditas, logam $\mathrm{Fe}$ dan $\mathrm{Cd}$ yang relatif rendah serta sedikit kandungan alkalinitas.

Interpretasi lainnya adalah sejumlah kolom menunjukkan indikasi potensi pembentukan air asam tambang yang kurang ataupun rendah. Indikasi tersebut ditemukan pada kolom; 
1. Kolom $\mathrm{B}$; dicirikan oleh $\mathrm{pH}$, konduktivitas, alkalinitas yang normal serta asiditas, kandungan sulfat, dan kandungan logam terlarut yang relatif rendah.

2. Kolom $\mathrm{C}$; memiliki nilai $\mathrm{pH}$ relatif normal, dan nilai asiditas serta kandungan logam yang rendah.

3. Kolom F; memiliki $\mathrm{pH}$ yang sangat tinggi, dan nilai asiditas dan kandungan logam yang rendah.

4. Kolom I; memiliki nilai $\mathrm{pH}$ normal, nilai asiditas dan kandungan logam yang rendah.

\subsection{Pengaruh Model Kolom terhadap} Pembentukan Air Asam Tambang

Karakteristik potensi pembentukan air asam tambang pada model kolom uji menunjukkan ada 6 kolom yang berpotensi dan 4 kolom tidak berpotensi untuk pembentukan air asam tambang. Mencermati kedua kondisi tersebut, maka dilakukan pendekatan tentang pengaruh susunan material yang dalam hal ini dinyatakan sebagai model kolom. Perbedaan model kolom menjadi informasi penting dalam perencanaan disposal dan penimbunan material perlu mempertimbangkan hal-hal berikut;

1. Sampel PAF yang juga digolongkan dalam PAF-HC sangat berpotensi dalam membentuk asam apalagi dalam jumlah tonase yang besar.

2. Sampel NAF belum cukup mampu untuk menetralisir keasaman yang berlebih yang dihasilkan sampel PAF. Sampel NAF baik digunakan dalam membuat timbunan karena tidak menimbulkan air asam tambang.

3. Sampel FABA sangat baik untuk digunakan dalam mencegah pembentukan keasaman tetapi dengan mempertimbangkan jumlah tonase dikarenakan sifat dari FABA yang sangat basa (alkali).

4. Letak lapisan material PAF tidak boleh berada paling atas karena akan terpapar langsung oleh udara sehingga terjadi pembentukan asam yang optimal. Sampel PAF juga tidak boleh berada paling bawah karena berakibat pada lapisan akhir yang dilewati air pelindian apalagi dalam jumlah tonase yang besar. Hal tersebut akan kembali membentuk asam yang dibantu oleh aktivitas mikroba.
5. Letak lapisan PAF agar tidak membentuk asam diletakkan berada di tengah agar terhindar dari udara bebas. Lapisan tersebut diapit oleh NAF dan FABA karena jika hanya menggunakan material NAF belum mampu menetralisir keasaman yang terbentuk.

6. Pencampuran antara sampel NAF, PAF, dan FABA sangat bagus dalam mencegah pembentukan asam dengan mempertimbangkan volume sampel.

Hasil penelitian ini juga didapatkan sifat fisik dari masing-masing sampel selama dilakukan pelindian. Sampel PAF memiliki sifat meloloskan air dengan baik, sedangkan sampel NAF dan FABA akan mengeras bila terkena udara dan air.

\section{Kesimpulan}

Uji statik terhadap sampel material yang diperoleh dari lokasi penambang berupa Mud SP3 Wara termasuk dalam kriteria Uncertain (UC) karena dapat digolongkan sebagai tipe 2 (PAFLC) yang diindikasi oleh NAPP bernilai negatif, dan sebagai tipe 1 (NAF) yang diindikasikan oleh $\mathrm{NAG} \mathrm{pH} \leq 4.5$. Material tersebut termasuk dalam kriteria yang berpotensi untuk pembentukan air asam tambang.

Rekayasa pembuatan 10 variasi kolom pelindian berdasarkan susunan dan komposisi material dengan menggunakan NAF, PAF, dan FABA menunjukkan potensi pembentukan yang berbeda. Penempatan PAF pada lapisan atas mengindikasikan kolom yang berpotensi untuk pembentukan air asam tambang yang terlihat pada kolom A, D, dan G. Hal serupa terjadi bilamana kolom diisi dengan prosentase PAF $\geq$ $50 \%$ dari volume total kolom yang terlihat pada kolom E dan H. Pencampuran material PAF, NAF dan PABA dengan komposisi PAF > 50\% mengindikasikan material tersebut tidak berpotensi untuk pembentukan air asam tambang.

\section{Ucapan Terimakasih}

Ucapan terima kasih disampaikan kepada Bapak Wahyu Putra Hartanto sebagai Kepala Laboratorium Geokimia PT. Adaro Indonesia atas dukungannya dalam melaksanakan penelitian ini. 


\section{Referensi}

[1] Said N. I., 2014. Teknologi Pengolahan Air Asam Tambang Batubara "Alternatif Pemilihan Teknologi". JAI. Vol.7 No. 2. Hal. 119 - 138.

[2] Smart R., Skinner W.M., Levay G., Gerson A.R., Thomas J.E., Sobieraj H., Schumann R., Weisener C.G., Weber P.A., Miller S.D., Stewart W.A., 2002. ARD Test Handbook: Project P387, A Prediction and Kinetic Control of Acid Mine Drainage. AMIRA, International Ltd., Melbourne, Australia, p. 42.
[3] Environmental Protection Agency (EPA) U.S. 2011. Method 1627: Kinetic Test Method for the Prediction of Mine Drainage Quality. Office of Water Office of Science and Technology Engineering and Analysis Division (4303T) 1200 Pennsylvania Avenue, NW. Washington, DC. P. 37. 